\title{
Life-Threatening Sochi Virus Infections, Russia
}

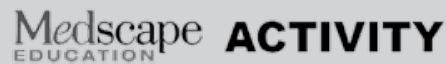

Medscape, LLC is pleased to provide online continuing medical education (CME) for this journal article, allowing clinicians the opportunity to earn CME credit.

This activity has been planned and implemented in accordance with the Essential Areas and policies of the Accreditation Council for Continuing Medical Education through the joint providership of Medscape, LLC and Emerging Infectious Diseases. Medscape, LLC is accredited by the ACCME to provide continuing medical education for physicians.

Medscape, LLC designates this Journal-based CME activity for a maximum of 1.0 AMA PRA Category 1 Credit(s) ${ }^{T M}$. Physicians should claim only the credit commensurate with the extent of their participation in the activity.

All other clinicians completing this activity will be issued a certificate of participation. To participate in this journal CME activity: (1) review the learning objectives and author disclosures; (2) study the education content; (3) take the post-test with a $75 \%$ minimum passing score and complete the evaluation at http://www.medscape.org/journal/eid; (4) view/print certificate.

Release date: November 12, 2015; Expiration date: November 12, 2016

\section{Learning Objectives}

Upon completion of this activity, participants will be able to:

- Analyze the demographics of patients infected with the Sochi virus in the current study

- Assess laboratory data available from patients infected with Sochi virus in the current study

- Distinguish the anatomic site of the highest concentration of Sochi virus among infected individuals

- Evaluate the prognosis of infection with Sochi virus.

\section{CME Editor}

Karen L. Foster, Technical Writer/Editor, Emerging Infectious Diseases. Disclosure: Karen L. Foster has disclosed no relevant financial relationships.

\section{CME Author}

Charles P. Vega, MD, Clinical Professor of Family Medicine, University of California, Irvine. Disclosure: Charles $P$. Vega, MD, has disclosed the following financial relationships: served as an advisor or consultant for Lundbeck, Inc.; McNeil Pharmaceuticals; Takeda Pharmaceuticals North America, Inc.

\section{Authors}

Disclosures: Detlev H. Kruger, MD, PhD; Evgeniy A. Tkachenko, MD, PhD; Vyacheslav G. Morozov, MD; Yulia V. Yunicheva, MD, PhD; Olga M. Pilikova, MD, PhD; Gennadiy Malkin, BS; Aydar A. Ishmukhametov, MD, PhD; Patrick Heinemann, PhD; Peter T. Witkowski, MD; Boris Klempa, PhD; and Tamara K. Dzagurova, MD, PhD, have disclosed no relevant financial relationships.

Detlev H. Kruger, Evgeniy A. Tkachenko, Vyacheslav G. Morozov, Yulia V. Yunicheva, Olga M. Pilikova, Gennadiy Malkin, Aydar A. Ishmukhametov, Patrick Heinemann, Peter T. Witkowski, Boris Klempa, Tamara K. Dzagurova

Author affiliations: Charité School of Medicine, Berlin, Germany (D.H. Kruger, P. Heinemann, P.T. Witkowski, B. Klempa); Chumakov Institute of Poliomyelitis and Viral Encephalitides, Moscow, Russia (E.A. Tkachenko, G. Malkin, A.A. Ishmukhametov, T.K. Dzagurova); Medical State University, Samara, Russia (V.G. Morozov);

Anti-Plague Stations, Sochi, Russia (Y.V. Yunicheva); Anti-Plague Stations, Novorossiysk, Russia(O.M. Pilikova); Slovak Academy of Sciences, Bratislava, Slovakia (B. Klempa)

DOI: http://dx.doi.org/10.3201/eid2112.150891
Sochi virus was recently identified as a new hantavirus genotype carried by the Black Sea field mouse, Apodemus ponticus. We evaluated 62 patients in Russia with Sochi virus infection. Most clinical cases were severe, and the case-fatality rate was as high as $14.5 \%$.

$\mathrm{H}$ antaviruses are zoonotic pathogens transmitted from small animals to humans. Hantavirus disease in the Americas is called hantavirus pulmonary syndrome and in Asia and Europe is called hemorrhagic fever with renal syndrome (HFRS). Both syndromes can lead to cardiopulmonary and renal failure (1). Recently we described a new hantavirus, Sochi virus, from the administrative region Krasnodar (including the city of Sochi), southern European Russia, which was isolated in cell culture from a Black Sea field mouse (Apodemus ponticus) and a 

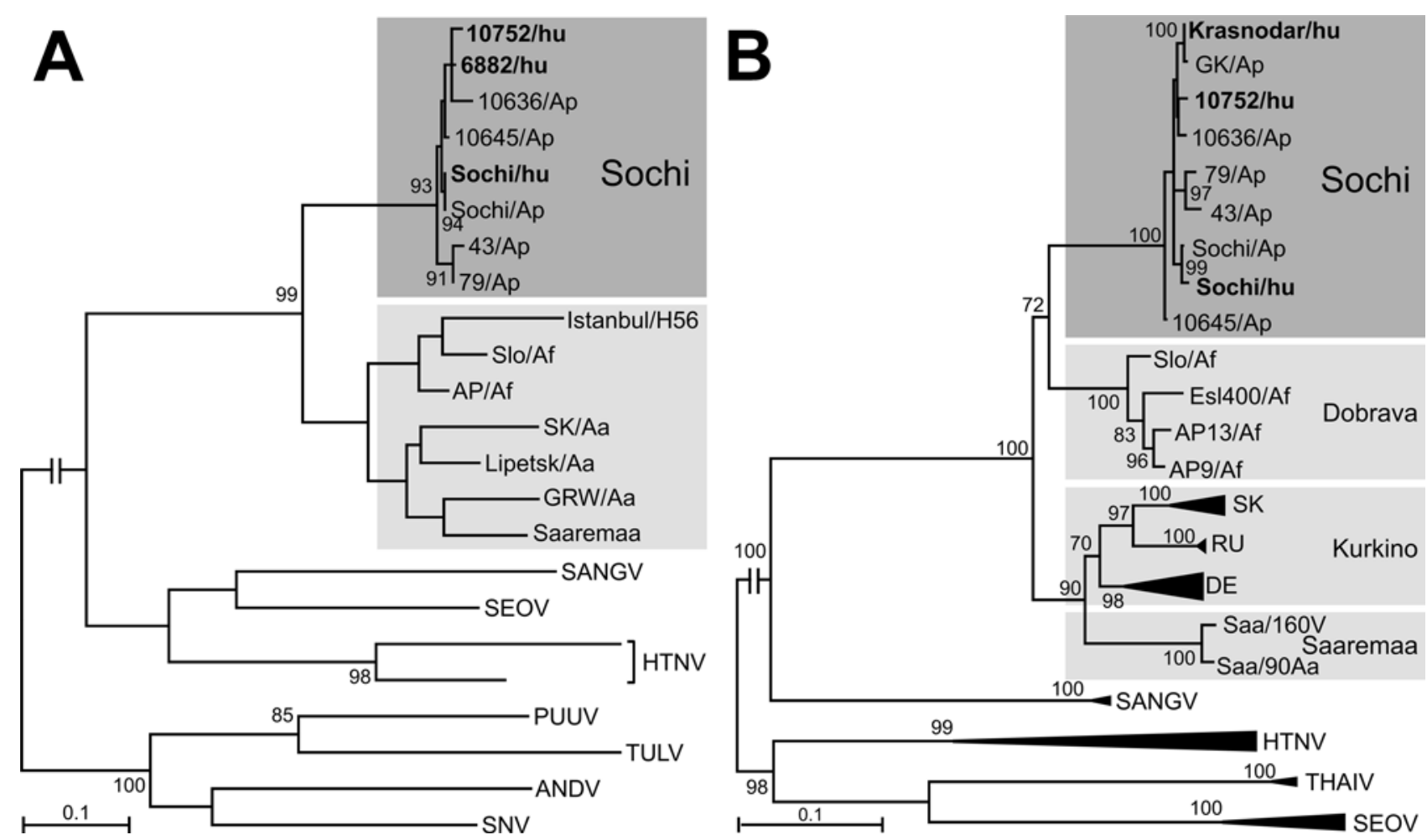

Figure 1. Phylogenetic analysis segment sequences of Sochi virus, Russia: A) 347-bp large (L) segment sequence; B) 1,197-bp small (S) segment sequence. Virus sequences derived from patients (shown in bold type) and Apodemus ponticus mice cluster within the Sochi genotype of DOBV. Evolutionary analysis was conducted in MEGA6 (6). The evolutionary history was inferred by using the maximum-likelihood method based on the Tamura 3-parameter model with a discrete gamma distribution and 5 rate categories (analysis in panel A) and on the general time reversible model with gamma rates and heterogeneous patterns (analysis in panel B), respectively, which were estimated to be the best-fit substitution model according to the Bayesian information criterion. Scale bars indicate an evolutionary distance of 0.1 substitutions per position in the sequence. Bootstrap values $\geq 70 \%$, calculated from 500 replicates, are shown at the tree branches. GenBank accession numbers of all sequences used in the analysis are listed in online Technical Appendix Table 1 (http://wwwnc.cdc.gov/EID/article/21/12/15-0891-Techapp1.pdf). Dark gray shading iindicates cluster of DOBV-Sochi strains; light gray shading indicates different clusters of strains from other DOBV genotypes. ANDV, Andes virus; DOBV, Dobrava-Belgrade virus; HTNV, Hantaan virus; PUUV, Puumala virus; SANGV, Sangassou virus; SEOV, Seoul virus; SNV, Sin Nombre virus; THAIV, Thailand virus; TULV, Tula virus.

patient with fulminant hantavirus disease who died of shock and combined kidney and lung failure (2-4). Molecular taxonomical analyses identified Sochi virus as a new genotype within the Dobrava-Belgrade virus (DOBV) species (5). Here we show that HFRS caused by Sochi virus infection occurs in the geographic region where A. ponticus mice are prevalent. For 62 patients infected by this virus during 2000-2013, we evaluated clinical and epidemiologic data.

\section{The Study}

Serum of patients with suspected acute hantavirus disease from the Krasnodar region were screened for hantavirus antibodies by indirect immunofluorescence assays and ELISA. Sixty-two patients showed clear DOBV IgG seropositivity. During the acute phase of illness, all patients tested positive for DOBV IgM (data not shown). For 26 patients, sufficient volumes of follow-up serum were available for additional focus reduction neutralization assays to specify neutralizing antibodies. All serum samples exhibited substantially higher neutralizing titers toward DOBV than toward Puumala virus, Hantaan virus, and Seoul virus. When the neutralizing effect of DOBVpositive patients' serum were compared against the different human pathogenic genotypes of DOBV (Dobrava, Kurkino, and Sochi), all serum predominantly reacted with the Sochi genotype (online Technical Appendix Table 1, http://wwwnc.cdc.gov/EID/article/21/12/15-0891Techapp1.pdf).

We successfully obtained virus genomic large (L) segment sequences from 2 patients (no. 51, specimen no. 6882; no. 59, specimen no. 10752). In the neighborhood 


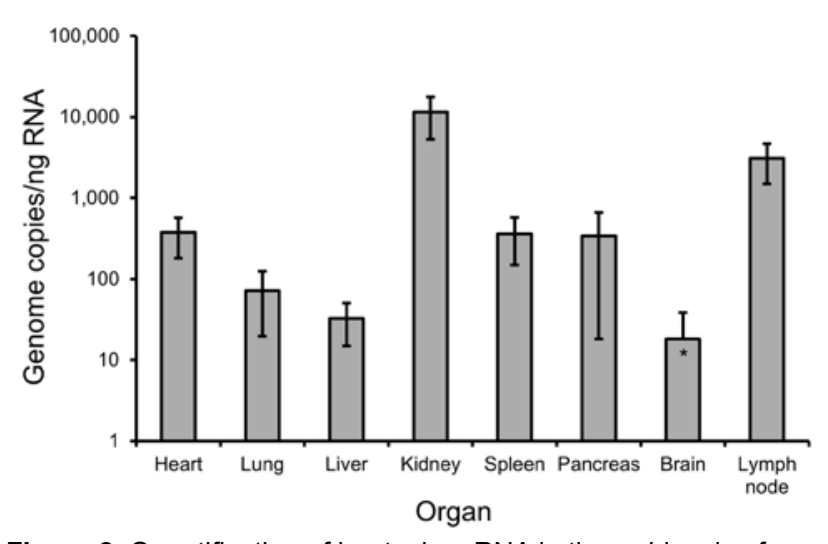

Figure 2. Quantification of hantavirus RNA in tissue biopsies from a 50-year-old Sochi virus-infected man (patient no. 59), Russia. Two independent approaches were performed to extract RNA from each organ. Quantitative reverse transcription PCR previously developed for DOBV (7) was used to measure virus load in the analyzed biopsy samples. Three quantitative reverse transcription PCR estimations were conducted for every RNA extraction, followed by calculation of mean values and SDs. Viral RNA levels are shown as genome copies per nanogram of total RNA isolated from the samples. Error bars indicate SD.

of the residence of patient no. 59, mice were trapped, and hantaviral L and small (S) segment regions from 2 A. ponticus animals (specimen nos. 10636, 10645) were amplified. The sequences obtained were deposited in GenBank under accession nos. KM192207-09 and KP878308-10 (L segment) and KP878311-13 (S segment) (online Technical Appendix Table 2). Samples from virus-positive mice were phylogenetically characterized by analysis of a 242-bp region of their $c y t B$ gene; all of them clustered with the previously identified $A$. ponticus animals (3) (data not shown). In addition, the $A$. ponticus-derived isolate Sochi/Ap (4), the patient-derived isolate Sochi/hu (5), an S segment sequence from a mouse (GK/Ap) trapped near the home of the previously described Krasnodar patient (4), and sequences originating from $2 \mathrm{~A}$. ponticus mice sampled near the Black Sea coast, 43/Ap and 79/Ap, were included in the molecular analyses of the virus.

The patient-derived sequences 6882/hu, 10752/hu, and Sochi/hu clearly cluster with $A$. ponticus-derived sequences 43/Ap, 79/Ap, 10636/Ap, 10645/Ap, and Sochi/Ap
(Figure 1, panel A). In the analysis of the S segment, we obtained a very similar result; the patient-derived sequences 10752/hu, Krasnodar/hu, and Sochi/hu cluster with $A$. ponticus-associated sequences 43/Ap, 79/Ap, 10636/Ap, 10645/Ap, GK/Ap, and Sochi/Ap (Figure 1, panel B). In analysis of both $\mathrm{L}$ and $\mathrm{S}$ segments, the Sochi virus strains form a unique group, clearly distinguishable from all other DOBV genotypes.

Specimens from different organs of deceased patient no. 59 were analyzed for virus load. The highest concentration was detected in kidney $(11,446$ copies/ng RNA) and lymph node (3,086 copies/ng RNA), whereas the least virus RNA (10-100 copies/ng RNA) was detected in lung, brain, and liver (Figure 2).

The clinical disease severity of the 62 Sochi virus-infected patients investigated (Table 1) was subdivided into mild, moderate, or severe following the standard Russian criteria (i.e., length of febrile phase, minimal blood pressure in the hypotonic phase, extent of hemorrhagic symptoms, minimal urine production, serum creatinine level, and extent of proteinuria) (online Technical Appendix Table 3 ). The case-fatality rate (CFR) was as high as $14.5 \%$ (9/62 patients). Including fatalities, severe disease developed in nearly $60 \%$ of patients, whereas the remaining $40 \%$ of cases were moderate. The average age of all patients was 33 years. A significantly higher proportion of patients were males $\left(\mathrm{p}=1.05 \times 10^{-9}\right)$. Moreover, severe disease developed in most affected male patients $(66.7 \%)$ but in only $35.7 \%$ of affected female patients $(p=0.037)$. The fact that only 2 of 9 fatal cases occurred in female patients (Table 1) underscores this finding.

All 9 patients with fatal infections died of multiorgan failure and shock (Table 2). Postmortem examination showed multiple hemorrhages and edema in internal organs, including kidneys and lungs. The patients died within 8.2 days (range $3-16$ days) after disease onset. An extraordinary fulminant course was observed for patient no. 47 , who died 3 days after onset and before he could be hospitalized. This 19-year-old man was the son-in-law of patient no. 48 , who also died after Sochi virus infection. Both men lived at the same rural address, and rodent contact during work in haystacks was reported.

\begin{tabular}{|c|c|c|c|c|c|c|}
\hline \multirow[b]{2}{*}{ Characteristic } & \multicolumn{2}{|r|}{ Total } & \multicolumn{2}{|c|}{ Sex, no. (\%) } & \multicolumn{2}{|c|}{ Age, $y, n / N(\%)$} \\
\hline & No. (\%) & Median age, y (range) & $\mathrm{M}, \mathrm{n}=48$ & $\mathrm{~F}, \mathrm{n}=14$ & $7-15$ & $>15$ \\
\hline No. patients & $62(100)$ & $33.3(7-57)$ & $48(77.4)$ & $14(22.6)$ & $6 / 62(9.7 \%)$ & $56 / 62(90.3)$ \\
\hline Outcome & & & & & & \\
\hline $\begin{array}{l}\text { Died } \\
\text { Survived }\end{array}$ & $\begin{array}{c}9(14.5) \\
53(85.5)\end{array}$ & $\begin{array}{c}38.6(19-53) \\
32.4(7-57)\end{array}$ & $\begin{array}{c}7(14.6) \\
41(85.4)\end{array}$ & $\begin{array}{c}2(14.3) \\
12(85.7)\end{array}$ & $\begin{array}{c}0 / 6 \\
6 / 6(100)\end{array}$ & $\begin{array}{c}9 / 56(16.1) \\
47 / 56(83.9)\end{array}$ \\
\hline Illness course & & & & & & \\
\hline $\begin{array}{l}\text { Severe, including fatal } \\
\text { Moderate, mild }\end{array}$ & $\begin{array}{l}37(59.7) \\
25(40.3)\end{array}$ & $\begin{array}{c}33.1(10-57) \\
33.6(7-57)\end{array}$ & $\begin{array}{l}32(66.7) \\
16(33.3)\end{array}$ & $\begin{array}{l}5(35.7) \\
9(64.3)\end{array}$ & $\begin{array}{l}3 / 6(50) \\
3 / 6(50)\end{array}$ & $\begin{array}{l}34 / 56(60.7) \\
22 / 56(39.3)\end{array}$ \\
\hline
\end{tabular}


Table 2. Characteristics of 9 deceased patients with Sochi virus infection, Russia*

\begin{tabular}{|c|c|c|c|c|c|c|c|}
\hline $\begin{array}{l}\text { Patient } \\
\text { no. }\end{array}$ & $\begin{array}{l}\text { Age, } \\
\text { y/sex }\end{array}$ & $\begin{array}{l}\text { Hospitalized, } \\
\text { no. d after } \\
\text { onset }\end{array}$ & $\begin{array}{c}\mathrm{Gl} \\
\text { symptoms }\end{array}$ & $\begin{array}{l}\text { Max serum } \\
\text { creatinine, } \\
\mu \mathrm{mol} / \mathrm{L} \dagger\end{array}$ & $\begin{array}{l}\text { Min platelet } \\
\text { count, } \\
\times 10^{9} / \mathrm{L} \ddagger \\
\end{array}$ & $\begin{array}{l}\text { Died, no. d } \\
\text { after onset }\end{array}$ & Clinical and postmortem findings \\
\hline 23 & 33/M & 5 & No & 148 & 70 & 8 & $\begin{array}{l}\text { Pneumonia; renal, cardiovascular, } \\
\text { multiorgan failure; multiple internal } \\
\text { hemorrhages, edema }\end{array}$ \\
\hline 29 & 29/M & Same day & Yes & 282 & 115 & 6 & $\begin{array}{l}\text { Renal, cardiovascular, multiorgan failure; } \\
\text { multiple internal hemorrhages, edema }\end{array}$ \\
\hline 30 & $47 / F$ & 5 & Yes & 391 & 38 & 12 & $\begin{array}{l}\text { Renal, lung failure; shock; coagulation } \\
\text { disturbance; hemorrhagic gastroenteritis; } \\
\text { multiple internal hemorrhages, edema }\end{array}$ \\
\hline 34 & $53 / \mathrm{M}$ & 3 & Yes & 250 & 110 & 10 & $\begin{array}{c}\text { Multiorgan failure; coagulation } \\
\text { disturbances; multiple internal } \\
\text { hemorrhages }\end{array}$ \\
\hline 42 & $30 / \mathrm{M}$ & 14 & Yes & 186 & 67 & 16 & $\begin{array}{l}\text { Uremic coma; multiorgan failure; multiple } \\
\text { internal hemorrhages }\end{array}$ \\
\hline $47 \S$ & $41 / \mathrm{M}$ & $\begin{array}{l}\text { Died before } \\
\text { hospitalization }\end{array}$ & Yes & NR & NR & 3 & $\begin{array}{c}\text { Renal failure; multiple internal } \\
\text { hemorrhages, edema }\end{array}$ \\
\hline $48 \S$ & 19/M & 4 & Yes & 192 & 54 & 6 & $\begin{array}{l}\text { Renal, cardiovascular failure; RDS, DIC } \\
\text { syndrome; bleedings in pituitary, adrenal } \\
\text { gland, intestinum, etc. }\end{array}$ \\
\hline 56 & $35 / F$ & 4 & Yes & 410 & 49 & 6 & $\begin{array}{l}\text { Cardiovascular, renal, lung, liver failure; } \\
\text { renal tubular necrosis; lung, brain edema }\end{array}$ \\
\hline 59 & $50 / \mathrm{M}$ & 5 & Yes & 310 & 3 & 7 & $\begin{array}{l}\text { Renal,cardiovascular failure; RDS; } \\
\text { multiple internal hemorrhages; } \\
\text { pleurorrhea; lung, brain edema }\end{array}$ \\
\hline
\end{tabular}

\section{Conclusions}

We have demonstrated the occurrence of human infections by Sochi virus and studied the clinical outcome for 62 patients. This virus is carried by the Black Sea field mouse (A. ponticus), which occurs naturally in the Transcaucasian region between the Black and Caspian Seas, including a part of southern European Russia. In anecdotal field studies in the coast region near Sochi, A. ponticus was the most abundant mouse species ( $71 \%$ of all trapped mice were identified as $A$. ponticus); moreover, $14 \%$ of trapped $A$. ponticus mice were serologically proven to be DOBV infected (8). This finding indicates that DOBV is the hantavirus indigenous in this geographic area and that A. ponticus mice are highly relevant as a hantavirus reservoir. All evidence from the natural virus reservoir, as well as serologic and molecular diagnostics of patients' serum, shows that the virus responsible for the infections is the DOBV genotype Sochi.

Most investigated patients found to be infected by Sochi virus exhibited a severe clinical course. With a calculated CFR of $14.5 \%$, Sochi virus might be the most deadly hantavirus outside the Americas, where $35 \%-50 \%$ of hantavirus infections are fatal $(1,9)$. Even Asian Hantaan virus is estimated to be less deadly; recent studies show CFRs of $1 \%-3 \%$ in China and South Korea, where Hantaan virus infections play an important role in HFRS morbidity $(10,11)$. On the other hand, increased awareness in diagnostics, treatment, and prevention by local physicians and public health authorities is expected to improve survival rates for Sochi virus infections.

Among the related viruses of the DOBV species, Sochi virus seems to have the highest level of virulence, similar to Dobrava virus (carried by A. flavicollis mice), which has a CFR of up to $10 \%-12 \%(12,13)$. As shown in larger studies, disease caused by infection with the related Kurkino genotype (carried by the western lineage of A. agrarius mice) is associated with a CFR of only $0.3 \%-0.9 \%(3,14)$. These phylogenetically related viruses exert a quite different pathogenicity in humans.

\section{Acknowledgments}

We thank Brita Auste for careful execution of the molecular diagnostics.

This work was supported by Russian Science Foundation (grant no. 14-15-00619), Robert Koch Institute on behalf of the German Ministry of Public Health (grant no. 1369-382), and Deutsche Forschungsgemeinschaft (Priority Program 1596 "Ecology and species barriers in emerging viral diseases," grant no. KR1293/13-1).

Dr. Kruger is the head of the Institute of Medical Virology, Charité-University Medicine Berlin. His research focuses on the molecular epidemiology and clinical relevance of emerging virus infections. 


\section{References}

1. Kruger DH, Figueiredo LTM, Song JW, Klempa B. Hantavirusesglobally emerging pathogens. J Clin Virol. 2015;64:128-36. http://dx.doi.org/10.1016/j.jcv.2014.08.033

2. Tkachenko EA, Okulova NM, Yunicheva YV, Morzunov SP, Khaǐbulina SF, Riabova TE, et al. The epizootological and $\mathrm{v}$ irological characteristics of a natural hantavirus infection focus in the subtropic zone of the Krasnodarsk Territory [in Russian]. Vopr Virusol. 2005;50:14-9.

3. Klempa B, Tkachenko EA, Dzagurova TK, Yunicheva YV, Morozov VG, Okulova NM, et al. Hemorrhagic fever with renal syndrome caused by 2 lineages of Dobrava hantavirus, Russia. Emerg Infect Dis. 2008;14:617-25. http://dx.doi.org/10.3201/ eid1404.071310

4. Dzagurova TK, Witkowski PT, Tkachenko EA, Klempa B, Morozov VG, Auste B, et al. Isolation of Sochi virus from a fatal case of hantavirus disease with fulminant clinical course. Clin Infect Dis. 2012;54:e1-4. http://dx.doi.org/10.1093/cid/cir746

5. Klempa B, Avsic-Zupanc T, Clement J, Dzagurova TK, Henttonen H, Heyman P, et al. Complex evolution and epidemiology of Dobrava-Belgrade hantavirus: definition of genotypes and their characteristics. Arch Virol. 2013;158:521-9. http://dx.doi.org/10.1007/s00705-012-1514-5

6. Tamura K, Stecher G, Peterson D, Filipski A, Kumar S. MEGA6: molecular evolutionary genetics analysis version 6.0. Mol Biol Evol. 2013;30:2725-9. http://dx.doi.org/10.1093/ molbev/mst197

7. Kramski M, Meisel H, Klempa B, Krüger DH, Pauli G, Nitsche A. Detection and typing of human pathogenic hantaviruses by real-time reverse transcription-PCR and pyrosequencing. Clin Chem. 2007;53:1899-905. http://dx.doi.org/ 10.1373/clinchem.2007.093245

8. Okulova NM, Khliap LA, Varshavskii AA, Dzagurova TK, Iunicheva IV, Riabova TE, et al. Spatial structure of natural foci of hantavirus on the territory of northwestern Caucasus [in Russian]. Zh Mikrobiol Epidemiol Immunobiol. 2013; Sep-Oct:47-53.

9. Mertz GJ, Hjelle B, Crowley M, Iwamoto G, Tomicic V, Vial PA. Diagnosis and treatment of new world hantavirus infections. Curr Opin Infect Dis. 2006;19:437-42. http://dx.doi.org/10.1097/ 01.qco.0000244048.38758.1f

10. Zhang YZ, Zou Y, Fu ZF, Plyusnin A. Hantavirus infections in humans and animals, China. Emerg Infect Dis. 2010;16:1195-203. http://dx.doi.org/10.3201/eid1608.090470

11. Noh JY, Cheong HJ, Song JY, Kim WJ, Song KJ, Klein TA, et al. Clinical and molecular epidemiological features of hemorrhagic fever with renal syndrome in Korea over a 10-year period. J Clin Virol. 2013;58:11-7. http://dx.doi.org/10.1016/j.jcv.2013.06.027

12. Avsic-Zupanc T, Petrovec M, Furlan P, Kaps R, Elgh F, Lundkvist A. Hemorrhagic fever with renal syndrome in the Dolenjska region of Slovenia - a 10-year survey. Clin Infect Dis. 1999;28:860-5. http://dx.doi.org/10.1086/515185

13. Papa A, Antoniadis A. Hantavirus infections in Greece - an update. Eur J Epidemiol. 2001;17:189-94. http://dx.doi.org/10.1023/ A: 1017987104363

14. Dzagurova TK, Klempa B, Tkachenko EA, Slyusareva GP, Morozov VG, Auste B, et al. Molecular diagnostics of hemorrhagic fever with renal syndrome during a Dobrava virus infection outbreak in the European part of Russia. J Clin Microbiol. 2009;47:4029-36. http://dx.doi.org/10.1128/JCM.01225-09

Address for correspondence: Detlev H. Kruger, Institute of Medical

Virology, Helmut-Ruska-Haus, Charité-University Medicine Berlin,

Charitéplatz 1, D-10117 Berlin, Germany; email: detlev.kruger@charite.de

\section{Outbreak of a New Strain of Flu at a Fair}

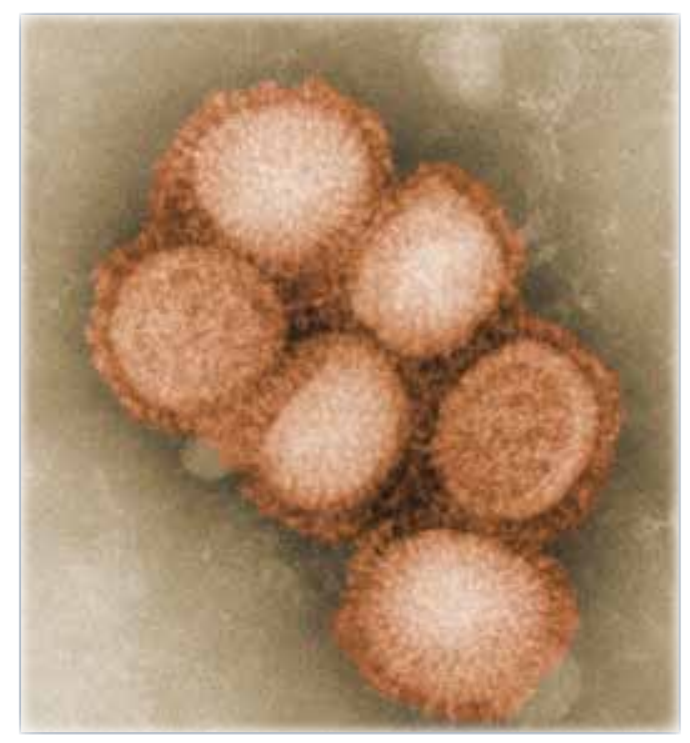

Dr. Karen Wong, an EIS officer with the Centers for Disease Control and Prevention, discusses her study about flu outbreaks at agricultural fairs.

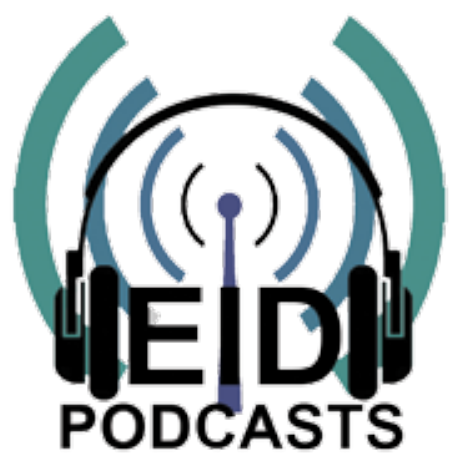

http://www2c.cdc.gov/podcasts/ player.asp? $\mathrm{f}=8627464$ 